\title{
Penerapan Kebijakan Pembangunan Berkelanjutan Di Lingkungan Kampus (Studi Perbandingan Antara Kampus Tembalang Universitas Diponegoro Dan Kampus Tertre Universitas Nantes)
}

\author{
Safrida Fatmawati', Joesron Ali Sjahbana²
}

Diterima : 10 September 2015

Disetujui : 31 dsesember 2015

\begin{abstract}
City is highly vulnerable to the impacts of climate change because of the large population, the intensive usage of infrastructure and a lot of economic activities. In addition, lifestyle and activity of urban communities, which neglect the impact of energy consumption, tend to increase the concentration of greenhouse gas involved in global warming. Improving the environment and the quality of life become the responsibility of all stakeholders, including the higher education institutions. They are the ones who have the contribution to conserve the environment. Sustainable Campus is a concept that began to develop in the world as a response to the environmental degradation which is integrated into the campus policy. This study proposes to compare the sustainable development policy within the Tertre campus, University of Nantes-France and Tembalang campus, Diponegoro University-Semarang, Indonesia. The material of this study was constituted through the interviews with the main stakeholders, as the key personnel in the field of sustainable development. In summary, we can conclude that the best sustainable development policy in the campus must be integrated into the environmental management, the improvement of the quality of life of the university community, and the strengthening of the economy, as well as engage in partnerships with all the stakeholders.
\end{abstract}

Keywords: Sustainable development, sustainable campus, Nantes University, Diponegoro University

\section{ABSTRAK}

Kota sangat rentan terhadap perubahan iklim akibat tingginya populasi, penggunaan infrastruktur yang intensif, serta banyaknya kegiatan ekonomi. Pola hidup dan aktivitas masyarakat yang mengabaikan prinsip hemat energi juga cenderung meningkatkan konsentrasi gas-gas rumah kaca sehingga memicu terjadinya pemanasan global.

Kata kunci: Pembangunan Berkelanjutan, Kampus Berkelanjutan, Universitas Nantes, Universitas Diponegoro

\section{PENDAHULUAN}

Pembangunan suatu kota di samping membawa dampak perubahan kota ke arah positif juga membawa dampak negatif, khususnya terkait masalah lingkungan. Menurunnya kualitas lingkungan merupakan salah satu dampak yang ditimbulkan akibat aktivitas pengembangan perkotaan. Berbagai aktivitas pembangunan cenderung mengarah pada pembangunan fisik yang berimbas pada pengurangan kuantitas ruang terbuka hijau, seperti pembangunan rumah, apartemen, dan gedung-gedung. Manajemen transportasi massal yang belum terkelola dengan

\footnotetext{
${ }^{1}$ Mahasiswa Magister Pembangunan Wilayah dan Kota, Fakultas Teknik, Universitas Diponegoro

Kontak penulis: safridafatmawati@yahoo.com

2 Dosen Magister Pembangunan Wilayahdan Kota, Undip Semarang, Jawa Tengah
} 
baik juga berdampak pada tingginya penggunaan kendaraan pribadi yang meningkatkan polusi udara. Lebih lanjut lagi, pola hidup dan aktivitas masyarakat yang mengabaikan prinsip hemat energi juga cenderung meningkatkan konsentrasi gas-gas rumah kaca sehingga memicu terjadinya pemanasan global. Kota sangat rentan terhadap perubahan iklim akibat tingginya populasi, penggunaan infrastruktur yang intensif, serta berbagai kegiatan ekonomi. Bermacam polusi dan gangguan telah menurunkan kualitas kehidupan dan lingkungan (Nicourt dan Girault, 1997). Kesadaran manusia dalam penggunaan energi seefisien mungkin menjadi dasar dalam pengelolaan sumber daya alam dan perlindungan lingkungan. Hal ini pula yang akhirnya mencetuskan ide konsep pembangunan berkelanjutan. Konsep "pembangunan berkelanjutan" dicetuskan setelah Earth Summit di Rio pada tahun 1992, yang fokus mengenai kondisi lingkungan global sebagai kelanjutan dari Konferensi PBB tentang lingkungan manusia yang diadakan di Stockholm tahun 1972 (Tubiana, 2000; Johnston, 2007; Wong, dkk, 2007; Thunis, 2010). Pembangunan berkelanjutan pertama kali didefinisikan dalam laporan Brundtland pada tahun 1987 yaitu "suatu konsep pembangunan yang memenuhi kebutuhan saat ini tanpa mengabaikan pemenuhan kebutuhan generasi mendatang" (Bovar dkk. 2008). Model dasar pembangunan berkelanjutan dipertimbangkan sebagai bentuk "triple bttom line" oleh John Elkington yang terdiri dari dimensi sosial, ekonomi, dan lingkungan (Johnston, 2007).

Perbaikan kondisi lingkungan dan peningkatan kualitas kehidupan menjadi tanggung jawab seluruh pihak, termasuk institusi perguruan tinggi. Keterlibatan perguruan tinggi dalam memperbaiki kondisi lingkungan diwujudkan melalui konsep kampus berkelanjutan. Konsep ini bertujuan untuk memperbaiki kesehatan manusia dan lingkungan alam, dengan mengefisiensikan penggunaan energi, mengurangi produksi sampah, polusi, dan degradasi lingkungan (B.Patal et P. Patal, 2012). Menurut Alshuwaikhat et Abubakar (2008), kampus berkelanjutan harus direalisasikan di dalam lingkungan kampus yang sehat melalui pengurangan konsumsi enerrgi dan sumber daya alam, produksi sampah, pengelolaan lingkungan, menjunjung keadilan sosial di setiap bidang, yang keseluruhan nilainya harus direpresentasikan di tingkat masyarakat, kota, dan nasional.

Namun sayangnya banyak universitas yang belum mengerti esensi dari kampus berkelanjutan ataupun membangun kampus yang berwawasan lingkungan. Di Indonesia, beberapa kampus menyatakan sudah menerapkan konsep kampus hijau, tetapi ternyata program yang dilakukan hanya berupa penanaman pohon yang sifatnya hanya seremonial. Pendeklarasian diri sebagai kampus hijau seharusnya tidak hanya mencakup satu aspek, yaitu penyediaan ruang terbuka hijau (RTH). Lebih dari itu, pelaksanaan konsep kampus hijau menekankan pada implementasi kebijakan dan program kampus ke dalam suatu konsep yang ramah lingkungan, efisiensi energi, maupun konservasi yang bersifat menyeluruh.

Kondisi sebaliknya dirasakan di Kota Nantes, Perancis, di mana universitas di kota tersebut dirasa sudah menerapkan konsep pembangunan berkelanjutan yang diintegrasikan ke dalam kebijakan universitas tanpa mendeklarasikan diri sebagai kampus hijau, ataupun dengan istilah yang lain. Hal ini dikarenakan pembangunan kota di Nantes sudah mengarah pada pembangunan berkelanjutan yang mencoba mensinergikan aspek lingkungan, ekonomi, dan sosial, termasuk dalam pengembangan lingkungan kampus. Kampus yang ada di Nantes pada umumnya menyediakan ruang terbuka hijau yang cukup, dapat dijangkau oleh transportasi publik, dan telah mengadopsi konsep green building.

Penelitian ini bertujuan untuk membandingkan penerapan kebijakan pembangunan berkelanjutan di Universitas Diponegoro, Semarang-Indonesia degan konsep "kampus hijau" dan l'Université de Nantes, Nantes-Perancis dengan konsep "kualitas dan pembangunan berkelanjutan". Melalui penelitian ini diharapkan dapat ditemukannya suatu konsep pembangunan berkelanjutan yang paling ideal untuk diterapkan di lingkungan kampus. 


\section{METODOLOGI PENELITIAN}

Pendekatan yang digunakan dalam penelitian kali ini berlandaskan filsafat postpositivisme, yaitu memandang realitas sosial sebagai sesuatu yang holistik karena setiap aspek merupakan satu kesatuan, dinamis, penuh makna, dan hubungan gejala bersifat interaktif (Sugiyono, 2006: 7). Metode penelitian yang digunakan adalah metode kualitataif yang termasuk kedalam jenis penelitian tindak, di mana peneliti bertindak sebagai instrumen kunci, teknik pengumpulan data yang dilakukan berupa wawancara dan analisis data bersifat induktif. Dalam penelitian kali ini, peneliti melakukan wawancara untuk mendapatkan informasi yang dapat mendeskripsikan tujuan detail dan motivasi universitas dalam menerapkan kebijakan pembangunan berkelanjutan.

Wawancara ini dilakukan kepada Wakil Presiden Universitas Nantes yang mengampu bidang aset properti dan bidang kualitas dan pembangunan berkelanjutan, serta kepada departemen kualitas dan pembangunan berkelanjutan Universitas Nantes (DQDD), departemen perencanaan, properti, dan logistik Universitas Nantes (DPIL), dan juga kepada asosiasi terkait. Selain itu peneliti juga melakukan wawancara kepada Mantan Rektor Universitas Diponegoro, Prof. Sudharto P. Hadi, serta kepada organisasi mahasiswa UNDIP seperti BEM UNDIP dan KSL. Penelitian ini didukung dengan dokumen terkait dari DQDD dan DPIL serta diverivikasi oleh surat kabar lokal dan nasional untuk memperkuat hasil analisis.

\section{GAMBARAN UMUM KAMPUS UNDIP TEMBALANG}

\section{Letak Administratif Kampus Undip Tembalang}

Kampus Tembalang, terletak di Kecamatan Tembalang dengan luas sekitar $1.720 .514 \mathrm{~m}^{2}$ yang digunakan untuk gedung perkuliahan dan membawahi 12 fakultas, Gedung Rektorat, Lembaga Penelitian, Lembaga Pengabdian kepada Masyarakat, Lembaga Pengembangan Pendidikan, UPT Perpustakaan, UPT Undip Press, LPPU, Rusunawa, GSG, dan Masjid Kampus.
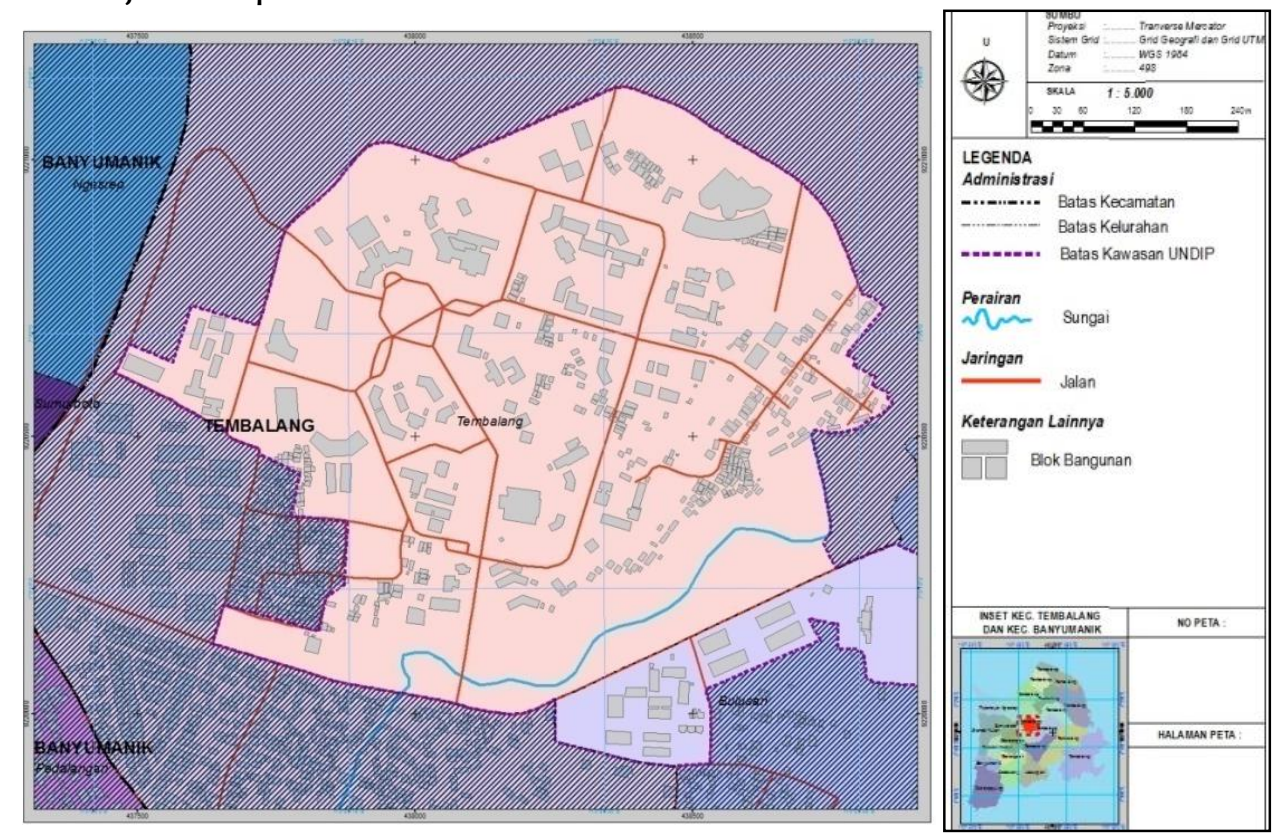

Sumber: Hasil Pengolahan Citra Satelit, 2010 


\section{Letak administrasi kampus Tertre, universitas Nantes}

Kampus tertre merupakan salah satu kampus Universitas Nantes yang terletak di quartier Nantes Utara, Perancis, di kawasan Petit Port di antara Sungai l'Erdre dan Hippodrme. Pada sisi timur, kampus Tertre dikelilingi oleh pepohonan pada sisi timur dan selatan. Kampus ini merupakan salah satu kampus tertua di Universitas Nantes yang dipusatkan untuk kegiatan perkuliahan oleh fakultas sastra, bahasa, dan ilmu sosial (les Lettres, Langues, Sciences Humaines et Sociale). Kampus ini memiliki luas sekitar $107.000 \mathrm{~m}^{2}$ dan dilayani oleh tramway jalur 2 serta 5 jalur bus.
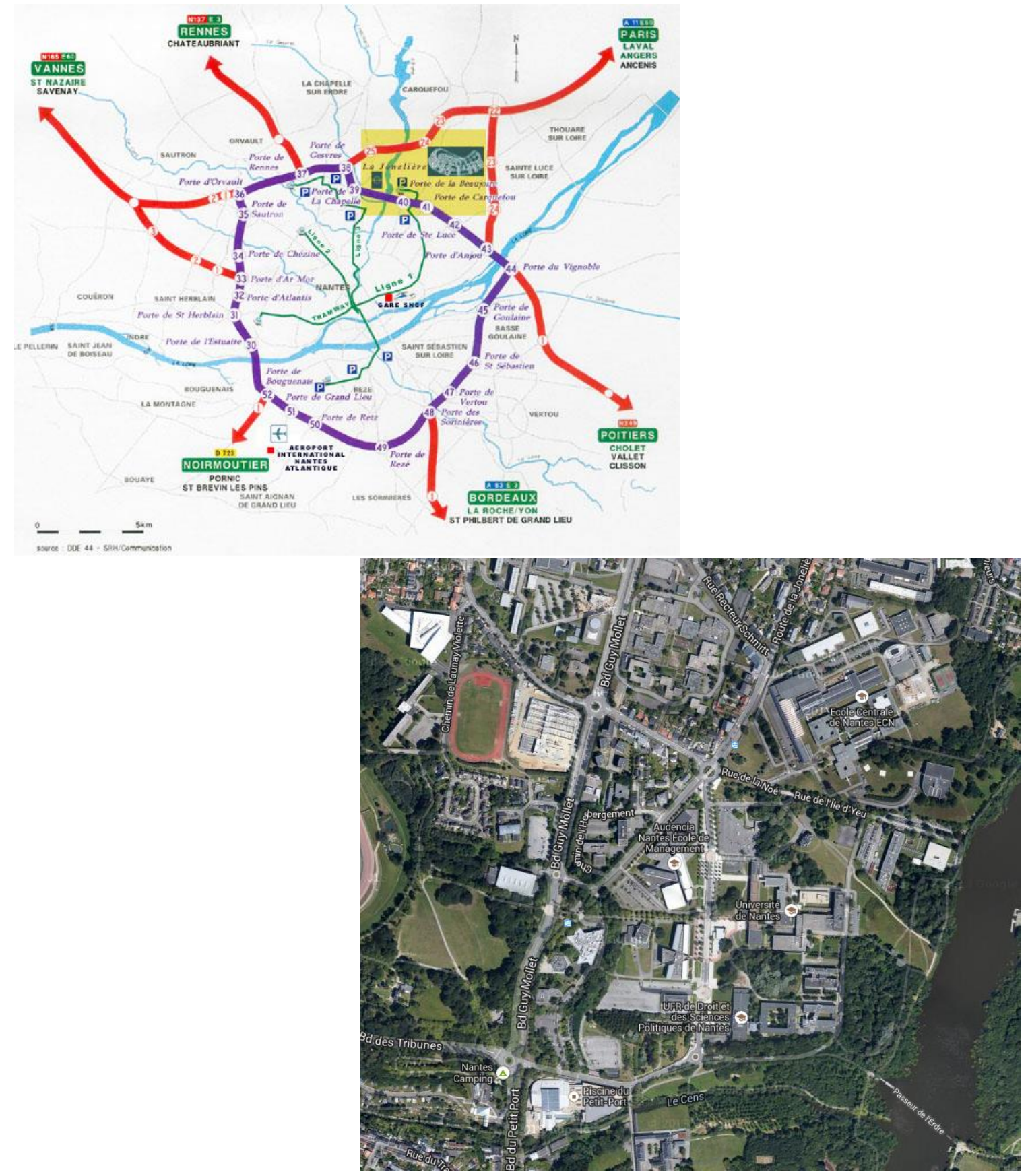


\section{KAJIAN TEORI}

\section{Peran perguruan tinggi dalam pembangunan berkelanjutan}

Soetomo (2012: 6) menjelaskan bahwa sektor pendidikan merupkan kunci utama dalam proses pengembangan wilayah yang didukung oleh masyarakat lokal. Namun pada kenyataannya sektor pendidikan yang ada tidak pernah dibangun melalui dasar kekuatan sumber daya lokal yang dapat dikembangkan oleh masyarakat lokal. Elemen dasar dalam pengembangan wilayah adalah ketersediaan sumber daya alam dan sumber daya manusia/teknologi. Dalam hal ini sektor pendidikan berperan sebagai pabrik pencetak sumber daya manusia yang ada dalam konsep pengembangan wilayah (Soetomo, 2012:7). Annan (2000), dalam Bekessy dkk. (2003) memberikan pandangannya bahwa peran edukasi sangat penting dalam mewujudkan konsep pembangunan berkelanjutan dan menghadapi tantangan yang ada di lingkungan sekitar kita sehingga badan pendidikan memegang peranan penting untuk membentuk masyarakat yang berwawasan lingkungan. Banyak istilah mulai bermunculan terkait dengan kampus dan lingkungan, mulai dari eko kampus, kampus berkelanjutan, dan juga kampus hijau.

\section{Eco Campus}

Istilah eko kampus menurut Badan Lingkungan Hidup (dalam Prasetyo, 2011) sendiri dapat dipahami sebagai kampus yang telah peduli dan berbudaya lingkungan dan telah melakukan pengelolaan lingkungan secara sistematis dan berkesinambungan. Dengan demikian eko kampus atau kampus yang berwawasan lingkungan harus dapat menciptakan keterlibatan seluruh warga kampus yang ada dalam lingkungan kampus agar selalu memperhatikan aspek lingkungan dalam aktivitasnya. Sebagai suatu institusi yang dianggap sebagai pusat intelektual, maka ada tuntutan moral pada kampus untuk dapat bertindak lebih bijak dan inovatif terhadap lingkungan sehingga memerlukan pemikiran-pemikiran yang memunculkan program-program ramah lingkungan (Salatin, 2011).

\section{Kampus Berkelanjutan}

Kampus yang berkelanjutan telah menjadi isu yang mengglobal. The Stockholm Declaration tahun 1972 telah membuka mata dunia tentang adanya ketergantungan antara manusia dan lingkungan sehingga memunculkan beberapa cara untuk mewujudkan lingkungan yang berkelanjutan (Alshuwaikhat dan Abubakar, 2008). Definisi kampus yang berkelanjutan menurut Meng, Abidin dkk. (2007) adalah kampus yang menjalankan dua sub-sistem dengan baik, yaitu ekosistem dan sistem manusianya. Sub-sistem ekosistem terdiri dari komponen material, udara, air, lahan, dan energi, sedangkan sub-sistem manusianya dibentuk dari pengetahuan, komunitas, kesehatan, kesejahteraan, dan kelembagaan.

\section{Kampus Hijau}

Kampus hijau merupakan konsep perpaduan antara lingkungan dengan dunia kampus dimana konsep lingkungan yang meliputi $3 R$, penghijauan, in front of office, CSR dan sebagainya digabung dengan konsep kampus yang terdiri dari fisik kampus, lokasi dan perilaku warga kampus. Sehingga dapat disimpulkan bahwa green campus merupakan kombinasi antara green building, green place dan green behaviour. Implementasi konsep green campus di beberapa perguruan tinggi disebut juga sebagai sebuah komunitas perguruan tinggi untuk meningkatkan efisiensi energi, melestarikan sumber daya dan meningkatkan kualitas lingkungan yang berkelanjutan serta menciptakan lingkungan belajar yang sehat (Humblet et al., 2010). 


\section{IDENTIFIKASI KEBIJAKAN PEMBANGUNAN BERKELANJUTAN DI LINGKUNGAN KAMPUS TEMBALANG}

\section{Konsep kebijakan kampus hijau di Kampus Tembalang Universitas Diponegoro}

Sekitar tahun 2010, saat Undip dipimpin oleh Prof. Sudharto yang merupakan seorang pakar lingkungan, pembangunan Undip mulai berorientasi ekologi dan Undip mulai melaksanakan program kampus hijau. Sejak tahun 2012, Undip telah aktif berpartisipasi dalam pemeringkatan sebagai kampus hijau terbaik di dunia oleh UI GreenMetric World University Ranking, dan menduduki peringkat 90 sebagai universitas terhijau di dunia pada tahun 2014. Di sisi lain, Undip juga ditunjuk oleh kementerian lingkungan hidup untuk menjadi salah satu kampus percontohan dalam pelaksanaan kampus hijau di Indonesia. Hal ini lah yang menjadi motivasi Undip dalam menerapkan kebijakan kampus hijau tersebut. Menurut Prof. Sudharto, pembangunan berkelanjutan di lingkungan kampus Undip Tembalang difokuskan dalam empat aspek, yaitu penataan drainase, pengelolaan sampah, pengelolaan transportasi, dan penambahan ruang terbuka hijau.

\section{Penataan Drainase}

Drainase di kawasan sekitar Kampus UNDIP Tembalang telah tersedia yaitu drainase primer berupa saluran yang menampung air hujan dan limbah berupa Sungai Seketak/Krengseng serta drainase sekunder berupa saluran yang menampung air/ limbah dari saluran sekunder yang terdapat disebelah kanan-kiri jalan utama/ jalan raya dan bangunan (Yulistiani, 2013). Penataan drainase di Kampus Tembalang dilakukan dengan : memperbaiki sistem surface drainage dan sub surface drainage; merencanakan sistem peresapan air yang dilakukan dengan membuat sumur resapan dan lubang biopori; dan membangun embung / waduk diponegoro.

\section{Pengelolaan Sampah}

Sampah merupakan merupakan bahan buangan padat yang berasal dari sisa aktivitas manusia sehari-hari. Banyaknya volume sampah dipengaruhi oleh jumlah individu yang menghasilkan sampah tersebut. Berdasarkan informasi dari situs Dinas Kebersihan dan Pertamanan Kota Semarang, kampus Undip Tembalang saat ini memiliki setidaknya 1.792 dosen, karyawan sekitar 1.100 orang, serta mahasiswa yang jumlahnya mencapai 35 ribu orang yang berarti berpotensi menghasilkan sampah yang sangat banyak. Setiap orang setidaknya berkontribusi menghasilkan 2,5-3 liter sampah setiap hari. Oleh karena itu pengelolaan sampah juga menjadi salah satu prioritas dalam penataan kampus Tembalang. Pengelolaan sampah di Kampus Tembalang dilaksanakan melalui 3 langkah: pengelolaan sampah di hulu; pembangunan 12 tempat penampungan sampah sementara; pembangunan tempat pengelolaan sampah terpadu.

\section{Pengelolaan Sistem Transportasi}

Pengelolaan sistem transportasi di Undip dilakukan dengan perbaikan jalur pedestrian untuk memfasilitasi para pejalan kaki. Selain itu UNDIP juga menyediakan persewaan sepeda gratis bagi civitas akademika dan menyelenggarakan car free day setiap hari jumat. UNDIP juga bekerja sama dengan pemerintah Kota Semarang dan Dinas Perhubungan Kota Semarang untuk menyediakan bus trans semarang yang melayani koridor kampus Undip. Rencananya akan ada delapan shelter yang akan dibangun di dalam lingkungan kampus UNDIP. Upayaupaya tersebut dilakukan untuk meminimalisir penggunaan kendaraan pribadi oleh warga kampus. 


\section{Penambahan Ruang Terbuka Hijau}

Penambahan ruang terbuka hijau (RTH) di UNDIP dilakukan dengan berbagai cara, seperti penanaman pohon, pembuatan taman, pembuatan hutan kampus, pembangungan "green house", pembangunan tempat untuk pembibitan tanaman langka, dan sebagainya.

Penanaman pohon di lingkungan Kampus UNDIP telah lama digalakkan. Pada tahun 2011, Rektor UNDIP telah menanam pohon sejumlah 14.600 dan dilanjutkan pada tahun 2012 dengan jumlah pohon mencapai 6.000 buah. Pohon-pohon tersebut ditanam di area yang minim pepohonan dan terasa gersang.Penanaman pohon ini bertujuan untuk menghijaukan kembali area kosong yang kurang diberdayakan disekitar lingkungan Kampus. Penanman pohon di Kampus UNDIP rutin dilakukan setiap hari Jumat usai melakukan senam pagi. Langkah ini sekaligus diambil sebagai pelaksanaan visi UNDIP sebagai universitas riset. Sementara itu, penyediaan Hutan Kampus UNDIP sebagai hutan edukasi merupakan salah satu bagian dari langkah konkret UNDIP dalam melaksanakan penghijauan. Hutan Kampus UNDIP terletak di belakang Fakultas IImu dan Budaya UNDIP.

\section{IDENTIFIKASI KEBIJAKAN PEMBANGUNAN BERKELANJUTAN DI KAMPUS TERTRE, UNIVERSITAS NANTES}

\section{Kronologi penerapan kebijakan pembangunan berkelanjutan di Universitas Nantes}

Pada tahun 2007, Universitas Nantes mulai menerapkan kebijakan pembangunan berkelanjutan dengan menyusun suatu Agenda 21 universitas yang memuat 21 aksi pembangunan berkelanjutan di dalam lima tema spesifik yaitu penelitian dan pengajaran, ketenagakerjaan, bangunan, karyawan universitas, serta pemerintahan. Sesuai instruksi dari l'article 55 de la loi du 3 août 2009, yang mengisyaratkan bahwa perguruan tinggi harus memiliki "peta hijau" untuk setiap kampusnya, maka Universitas Nantes mengintegrasikan rencana tersebut ke dalam Agenda 21 Universitas.

Pada tahun 2013, seiring dengan terpilihnya Wakil Presiden Universitas yang baru di bidang Kualitas dan Pembangunan Berkelanjutan, maka dibentuklah suatu departemen yang khusus menangani masalah kualitas dan pembangunan berkelanjutan di lingkungan kampus yang bernama DQDD (la Direction Qualité et Développement Durable). Departemen ini kemudian mengadakan pertemuan bersama stakeholders dan memutuskan untuk memperbarui kebijakan pembangunan berkelanjutan karena beberapa program tidak memiliki keterkaitan dengan strategi global universitas. Berdasarkan dialog tersebut, maka disusunlah suatu strategi baru bernama strategi "Qualité et Développement Durable" atau kualitas dan pembangunan berkelanjutan.

\section{Strategi Kualitas}

Strategi kualitas yang diterapkan oleh Universitas Nantes ini bertujuan untuk memperbaiki kualitas Universitas Nantes di segala bidang, baik di bidang pelayanan administrasi, penelitian, pengajaran, untuk mencapai standar universitas yang lebih baik di tingkat nasional maupun internasional.

\section{Strategi Pembangunan Berkelanjutan}

Strategi pembangunan berkelanjutan di Universitas Nantes dilakukan dengan dua strategi utama, yaitu transisi energi dan pengelolaan sampah. Strategi dalam transisi energi ini difokuskan untuk penghematan energi di Universitas Nantes karena 
meningkatnya biaya pengelolaan kampus. Energi yang dimaksud dalam hal ini adalah aliran listrik, air, penggunaan pemanas, dan sebagainya.

Strategi transisi energi di kampus Tertre dilakukan dengan merenovasi gedung dan merestrukturisasi jurusan-jurusan yang ada tanpa menambah bangunan baru yang berarti menghemat anggaran dan juga menghemat pengeluaran energi. Renovasi kampus Tertre ini bernama "Nouveau Tertre" yang berarti Tertre baru. Selain karena alasan bangunan yang sudah tua, renovasi ini dilakukan untuk mengoptimalkan ruang-ruang yang ada dengan pemakaian secara bergantian oleh setiap jurusan dan pengaturan jadwal penggunaan ruang yang lebih teratur, sehingga dapat memaksimalkan fungsi ruang dan penggunaan energi.

Sementara strategi pengolahan sampah dilakukan dengan pemetaan terhadap lokasilokasi yang berpotensi menimbulkan sampah, serta menyediakan tempat sampah terpisah antara sampah rumah tangga dan sampah yang dapat didaur ulang. Universitas Nantes bekerja sama dengan pemerintah kota dalam pengelolaan sampah yang dihasilkan dan menjembatani masyarakat kampus dalam memilah sampah dengan menyediakan tempat sampah yang terpisah. Setelah sampah dari universitas diangkut oleh dinas kebersihan kota, kemudian akan didistribusikan ke Politek Nantes untuk diolah. Selain itu, Universitas Nantes juga menerapkan strategi pengurangan produksi sampah dan optimalisasi penerapan kebijakan paperless.

\section{ANALISIS KEBIJAKAN PEMBANGUNAN BERKELANJUTAN DI UNDIP DAN DI UNIVERSITAS NANTES}

Perbandingan penerapan kebijakan pembangunan berkelanjutan di Universitas Diponegoro dan Universitas Nantes didasari atas beberapa faktor, antara lain faktor geografis, faktor kebudayaan, faktor kebijakan pembangunan daerah, faktor kepentingan universitas. Berbagai program kampus dilakukan dalam rangka mewujudkan upaya keberlanjutan yang disesuaikan dengan visi global tiap universitas. Perbedaan kepentingan dan lokasi geografi menjadi faktor dominan dalam menentukan strategi pembangunan berkelanjutan di lingkungan kampus.

\section{Faktor Geografis}

Secara geografis, Universitas Diponegoro dan Universitas Nantes terletak di dua negara dengan kondisi yang berbeda. UNDIP terletak di negara berkembang, di mana masalah pengelolaan lingkungan, pemerataan ekonomi, kemacetan, dan juga masalah kemiskinan masih menjadi isu utama pembangunan wilayah. Indonesia, di satu sisi merupakan negara tropis yang memiliki intensitas hujan yang tinggi. Di sisi lain pembangunan di Indonesia cenderung mengurangi daerah resapan air yang dapat memicu terjadinya banjir. UNDIP terletak di pulau Jawa yang merupakan pulau dengan tingkat kepadatan penduduk tertinggi di dunia. di sisi lain, UNDIP terletak di Kota Semarang yang memiliki kondisi yang unik, yaitu berupa daerah perbukitan di daerah pinggiran Semarang bagian selatan dan berupa dataran rendah di pusat kota. Kondisi ini menjadi salah satu kendala dalam penerapan sistem transportasi berupa trem, seperti yang ada di Kota Nantes ataupun kota-kota maju lainnya.

Hal ini sangat berbeda dengan kondisi yang ada di Kota Nantes, di mana isu utama pembangunan yang dihadapi bukan lagi masalah lingkungan ataupun kemacetan lalu 
lintas, tetapi terkait efisiensi energi. Nantes merupakan kota di negara dengan empat musim, sehingga membutuhkan perencaaan pembangunan wilayah yang berbeda dengan Semarang yang berada di negara tropis. Mahasiswa di Nantes sudah terbiasa berjalan kaki dengan didukung kondisi iklim yang sejuk dan kualitas udara yang baik. Berangkat ke sekolah saat matahari belum terbit ketika musim dingin adalah hal yang wajar bagi para pelajar di negeri empat musim. Dengan demikian, faktor geografis ini juga telah mempengaruhi kebiasaan mahasiswa sehari-hari.

\section{Faktor Kebudayaan}

Sebagai salah satu perguruan tinggi di Indonesia, Universitas Diponegoro mencoba mengintegrasikan nilai-nilai budaya bangsa Indonesia ke dalam sistem pengajaran dan pembentukan karakter bagi mahasiswa. Universitas Diponegoro menekankan pentingnya nilai sosial di dalam kehidupan bermasyarakat. Berbagai program pengembangan masyarakat dilaksanakan melalui kegiatan kampus, seperti Kuliah Kerja Nyata, Praktik Kerja Lapangan, dan kegiatan lain sebagai bentuk tanggung jawab sosial universitas dan untuk meningkatkan keaktifan mahasiswa dalam bersosialisasi di lingkungan masyarakat.

Adanya program tersebut dapat memupuk jiwa sosial mahasiswa sekaligus sebagai upaya pembentukan karakter mahasiswa, di mana mahasiswa memiliki kepedulian dan empati terhadap pembangunan lingkungan sekitar. Mahasiswa bahkan sudah dilibatkan dalam kegiatan pembangunan berkelanjutan di UNDIP sejak pertama kali menjadi mahasiswa, yaitu dengan mewajibkan mahasiswa baru untuk membawa bibit tanaman yang akan ditanam di lingkungan kampus guna penghijauan area kampus. Sebaliknya, Negara Perancis merupakan salah satu negara yang terkenal dengan penduduk yang memiliki sikap individualis sangat tinggi. Hal tersebut menjadi budaya hingga lingkungan universitas, di mana universitas kurang menerapkan kurikulum pendidikan yang menyasar pada pembangunan masyarakat secara luas. Mahasiswa tidak dilibatkan aktif dalam penyusunan kegiatan universitas.

Di Universitas Nantes, terdapat beberapa organisasi kemahasiswaan yang berafiliasi pada program pembangunan berkelanjutan, yaitu AMAP. Namun ternyata kegiatan mahasiswa tersebut hanya mendistribusikan produk-produk bio, yaitu produksi pertanian yang menggunakan bahan alami. Selain itu tidak ada organisasi kemahasiswaan yang terlibat langsung dalam kegiatan pembangunan berkelanjutan. Mahasiswa hanya terlibat saat ada kegiatan penelitian di bidang pembangunan berkelanjutan.

\section{Faktor Kebijakan Pembangunan Daerah}

Kondisi pertkembangan Semarang dan Nantes tentu saja berbeda. Semarang sedang menuju ke arah pembangunan berkelanjutan dan berusaha mengatasi masalahmasalah mendasar, seperti banjir, kemacetan lalu lintas, pengelolaan sampah, dan juga masalah pengembangan masyarakat. Hal tersebut mendorong perumusan program kerja di Undip difungsikan juga untuk mengatasi persoalan daerah Semarang. Sebagai contoh kegiatan perbaikan drainase dan pembuatan waduk Diponegoro. Undip terletak di kawasan perbukitan Semarang yang dahulunya merupakan daerah resapan. 
Perencanaan sistem draianase di kampus Undip penting karena kampus UNDIP Tembalang terletak di daerah perbukitan kota Semarang yang berfungsi sebagai kawasan resapan untuk mengurangi limpasan air ke wilayah yang lebih rendah.

Sedangkan Kota Nantes merupakan salah satu kota maju yang sudah terlebih dahulu menjadi kota yang memiliki tatanan rapi dan memperhatikan konsep pembangunan kota yang berkelankjutan. Kota Nantes telah menyediakan ruang terbuka hijau lebih dari 30\%. Manajemen transportasi dikelola sangat baik di kota tersebut sehingga sangat jarang dijumpai kemacetan akibat penumpukan mobil pribadi. Kesadaran masyarakat dalam melestarikan lingkungan sangat tinggi dan mereka terbiasa hidup dalam kondisi disiplin dan tertib hukum. Universitas Nantes secara tidak langsung sudah mewujudkan kebijakan yang mengarah pada program pembangunan berkelanjutan karena terletak di Kota Nantes yang telah menerapkan konsep pembangunan kota yang berkelanjutan dan didukung masyarakat yang sadar lingkungan. Hal itu berdampak pada penetapan strategi pembangunan yang tidak menempatkan aspek pelestarian lingkungan dan manajemen transportasi sebagai prioritas utama kebijakan universitas.

\section{Faktor Tingkat Kepentingan Universitas}

Dalam pelaksanaan kebijakannya, baik Universitas Diponegoro maupun Universitas Nantes belum menerapkan dimensi pembangunan berkelanjutan secara menyeluruh. Universitas Diponegoro menekankan konsep kebijakan yang lebih fokus terhadap masalah pengelolaan lingkungan. Hal ini dapat terlihat dari motivasi Universitas Diponegoro dalam mengembangkan kampus hijau adalah ingin mewujudkan kampus yang asri, teduh dan nyaman sehingga warga kampus merasa nyaman bekerja dan belajar dan mendorong peningkatan prestasi dan kinerja. Berdasarkantujuan tersebut, program kerja yang dirumuskan oleh UNDIP sebagian besar ditujukkan untuk perbaikan kualitas lingkungan.

Sementara Universitas Nantes cenderung lebih memperhatikan dimensi ekonomi diantara ketiga pilar pembangunan berkelanjutan. Berbagai program yang menjadi prioritas kebijakan pembangunan berkelanjutan di Universitas Nantes ditujukan untuk menghemat pengeluaran universitas, mulai dari renovasi gedung Tertre untuk menghindari pembangunan gedung baru dan menekan biaya perawatan, pengelompokkan jurusan untuk dapat memanfaatkan sarana dan prasarana di ruang yang sama sehingga menghemat energi, hingga menghubungkan jaringan pemanas dengan sistem pemanas Kota Nantes.

Kemudian terkait dimensi sosial, baik Universitas Diponegoro maupun Universitas Nantes telah memprioritaskan peningkatan kualitas pengajaran dan penelitian sebagai bagian dari keinginan mereka untuk mencapai pembangunan berkelanjutan. UNDIP bahkan sudah memasukkan tujuan ini ke dalam visi global UNDIP untuk menjadi universitas riset unggulan pada tahun 2020. Sementara Universitas Nantes ingin terus meningkatkan program pelatihan, penelitian dan perbaikan kualitas bagi semua aktor internal dan eksternal universitas. Pendekatan ini dilakukan dengan mendengarkan 
harapan dan mengukur tingkat kepuasan para pengguna dengan melibatkan semua orang universitas (manajemen, karyawan, mahasiswa).

Namun sayangnya, upaya UNDIP dalam rangka meningkatkan kualitas penelitian masih kurang optimal. Sebagai contoh pada saat pengumpulan data untuk penyusunan penelitian ini, penulis kesulitan mengakses data UNDIP baik dari internet maupun permohonan data langsung pada bagian administrasi. Hal itu ditunjukkan dengan tidak adanya data mengenai konsep pembangunan berkelanjutan yang seharusnya dapat diakses melalui situs UNDIP, adanya beberapa persyaratan administrasi permohonan data yang menghambat kegiatan penelitian, serta larangan permintaan data berupa peta perencanaan ataupun masterplan yang sebetulnya merupakan data penting dalam sebuah penelitian.

Sebaliknya, Universitas Nantes berusaha memfasilitasi mahasiswa dalam melakukan penelitian termasuk dalam hal pengumpulan data dan informasi yang dapat menunjang kegiatan penelitian. Data yang dapat diakses merupakan dokumen perencanaan, pelaporan berkala ataupun peta perencanaan. Penyederhanaan sistem administrasi dan birokrasi serta penyebarluasan informasi seputar universitas dengan memanfaatkan sistem komputasi ditujukan untuk memudahkan para peneliti dalam melakukan kegiatan penelitian. Dilihat dari aspek-aspek pelaksanaan kebijakan pembangunan berkelanjutan di Universitas Diponegoro dan di Universitas nantes, maka dirumuskan matriks perbandingan yang dapat dilihat pada tabel berikut.

TABEL 1

\section{PERBANDINGAN PENERAPAN KEBIJAKAN PEMBANGUNAN BERKELANJUTAN ANTARA UNDIP DAN UNIVERSITAS NANTES}

\begin{tabular}{|c|c|c|c|}
\hline Aspek & UNDIP & UNIVERSITAS NANTES & ANALISIS \\
\hline Stategi & - Kampus Hijau & $\begin{array}{l}\text { Kualitas dan Pembangunan } \\
\text { Berkelanjutan }\end{array}$ & $\begin{array}{l}\text { Penetapan strategi } \\
\text { didasarkan pada: } \\
\text { - Isu permasalahan yang } \\
\text { dihadapi } \\
\text { - Kebutuhan pengguna }\end{array}$ \\
\hline $\begin{array}{l}\text { Kesesuaian } \\
\text { dengan } \\
\text { Prinsip } \\
\text { Pembangun } \\
\text { an } \\
\text { Berkelanjut } \\
\text { an }\end{array}$ & $\begin{array}{l}\text { - Pilar Lingkungan } \\
\text { - Pilar Sosial }\end{array}$ & $\begin{array}{l}\text { - Pilar Ekonomi } \\
\text { - Pilar Sosial }\end{array}$ & $\begin{array}{l}\text { Kedua universitas belum } \\
\text { mensinergikan seluruh } \\
\text { prinsip pembanghunan } \\
\text { berkelanjutan ke dalam } \\
\text { sistem kebijakan universitas }\end{array}$ \\
\hline \multicolumn{3}{|c|}{ - Pengoperasian Kampus } & \multirow{3}{*}{$\begin{array}{l}\text { Program-program tersebut } \\
\text { merepresentasikan } \\
\text { kepentingan universitas. } \\
\text { Harus ada integrasi antara } \\
\text { prinsip-prinsip } \\
\text { pembangunan berkelanjutan } \\
\text { tetapi juga } \\
\text { mempertimbangkan strategi } \\
\text { untuk meningkatkan kualitas } \\
\text { hidup penggunaan }\end{array}$} \\
\hline $\begin{array}{l}\text { Konservasi } \\
\text { Lingkungan }\end{array}$ & $\begin{array}{l}\text { - Membangun sumur resapan } \\
\text { - Membuat lubang biopori } \\
\text { - Miponegoro } \\
\text { - Menanam pohon } \\
\text { - Membuat Hutan Kampus } \\
\text { - Membuat Taman Kampus }\end{array}$ & Tanpa keterangan & \\
\hline $\begin{array}{l}\text { Efisiensi } \\
\text { Energi }\end{array}$ & Tanpa keterangan & $\begin{array}{l}\text { - Merenovasi gedung } \\
\text { Tertre }\end{array}$ & \\
\hline
\end{tabular}




\begin{tabular}{|c|c|c|c|}
\hline Aspek & UNDIP & UNIVERSITAS NANTES & \begin{tabular}{|l} 
ANALISIS \\
\end{tabular} \\
\hline & & 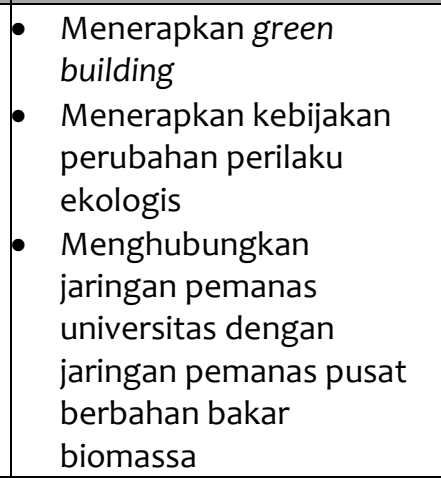 & (mahasiswa, staf ...) \\
\hline $\begin{array}{l}\text { Pengolahan } \\
\text { Sampah }\end{array}$ & $\begin{array}{l}\text { - Menyediakan tempat sampah } \\
\text { berdasarkan organik dan non } \\
\text { organik } \\
\text { - Membangun } 12 \text { TPS di dalam } \\
\text { kampus } \\
\text { - Membuat TPST }\end{array}$ & $\begin{array}{l}\text { Menyediakan tempah } \\
\text { sampah yang terpisah } \\
\text { antara sampah rumah } \\
\text { tangga, sampah yang } \\
\text { dapat didaur ulang, dan } \\
\text { sampah botol/kaca } \\
\text { Melakukan diagnosis dan } \\
\text { pemetaan sampah } \\
\text { berdasarkan tingkat } \\
\text { bahayanya } \\
\text { Mengurangi produksi } \\
\text { sampah }\end{array}$ & \\
\hline $\begin{array}{l}\text { Manajemen } \\
\text { Transportas } \\
i\end{array}$ & $\begin{array}{l}\text { - Mendorong penggunaan } \\
\text { sepeda ke kampus } \\
\text { - Memperbaiki trotoar dan jalur } \\
\text { pedestrian } \\
\text { - Mengurangi jumlah kendaraan } \\
\text { pribadi }\end{array}$ & Tanpa keterangan & \\
\hline $\begin{array}{l}\text { Pendidikan } \\
\text { dan } \\
\text { Penelitian }\end{array}$ & $\begin{array}{l}\text { Memasukkan ilmu } \\
\text { pembangunan berkelanjutan } \\
\text { sebagai mata kuliah pada } \\
\text { beberapa jurusan/program } \\
\text { studi } \\
\text { - Melakukan penelitian di } \\
\text { bidang pembangunan } \\
\text { berkelanjutan }\end{array}$ & $\begin{array}{l}\text { - Memiliki program studi } \\
\text { khusus tentang } \\
\text { Pembangunan } \\
\text { Berkelanjutan } \\
\text { - Memasukkan ilmu } \\
\text { pembangunan } \\
\text { berkelanjutan sebagai } \\
\text { mata kuliah pada } \\
\text { beberapa } \\
\text { jurusan/program studi } \\
\text { - Melakukan penelitian di } \\
\text { bidang pembangunan } \\
\text { berkelanjutan }\end{array}$ & $\begin{array}{l}\text { Kedua universitas telah } \\
\text { mengintegrasikan aspek } \\
\text { pendidikan dan } \\
\text { penelitian ke dalam } \\
\text { penerapan kebijakan } \\
\text { pembangunan } \\
\text { berkelanjutan sebagai } \\
\text { bentuk representasi } \\
\text { peningkatan kualitas } \\
\text { masyarakat universitas. }\end{array}$ \\
\hline $\begin{array}{l}\text { Aktor } \\
\text { Pelaksana }\end{array}$ & $\begin{array}{l}\text { - Dosen dan karyawan } \\
\text { - Mahasiswa }\end{array}$ & 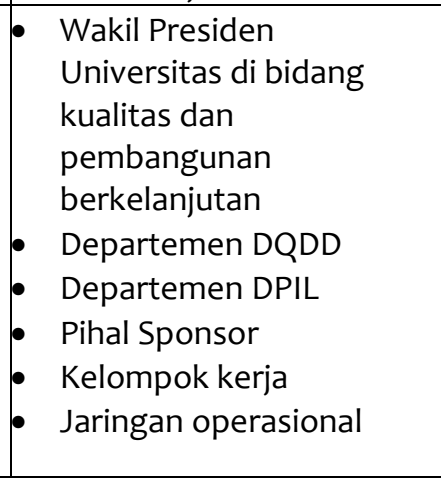 & $\begin{array}{l}\text { Tidak ada } \\
\text { departemen/biro yang } \\
\text { bertanggung jawab } \\
\text { menangani pelaksanaan } \\
\text { kebijakan ini. Hanya ada } \\
\text { tim khusus untuk menata } \\
\text { kampus Tembalang yang } \\
\text { terdiri dari beberapa ahli } \\
\text { yang juga dosen di } \\
\text { Undip. } \\
\text { - Undip juga menunjukkan }\end{array}$ \\
\hline
\end{tabular}




\begin{tabular}{|c|c|c|c|}
\hline Aspek & UNDIP & UNIVERSITAS NANTES & ANALISIS \\
\hline & & & $\begin{array}{l}\text { bahwa ada kontribusi } \\
\text { mahasiswa dalam } \\
\text { pelaksanaan kebijakan } \\
\text { ini. } \\
\text { - Sebaliknya, Universitas } \\
\text { Nantes memiliki } \\
\text { departemen DQDD yang } \\
\text { fokus terhadap } \\
\text { pelaksanaan strategi } \\
\text { pembangunan } \\
\text { berkelanjutan di } \\
\text { universitas. Namun, tidak } \\
\text { ada partisispasi dari } \\
\text { mahasiswa Universitas } \\
\text { Nantes di dalamnya }\end{array}$ \\
\hline
\end{tabular}

Sumber: Hasil Analisis Peneliti, 2015

\section{KESIMPULAN}

Berdasarkan analisis yang dilakukan, dapat disimpulkan bahwa penentuan kebijakan pembangunan berkelanjutan di setiap universitas didasari pada permasalahan yang dihadapi serta untuk memenuhi kebutuhan pengguna. Sebagian besar universitas di Indonesia mengadopsi konsep kampus hijau sebagai konsep utama dalam mewujudkan pembangunan berkelanjutan. Sementara di Perancis tidak ada istilah khusus untuk sistem kebijakan yang diambil. Perbedaan penetapan kebijakan pembangunan berkelanjutan antara Universitas Diponegoro dan Universitas Nantes antara lain dipengaruhi oleh faktor geografis, faktor kebudayaan, faktor kebijakan pembangunan daerah, dan faktor kepentingan universitas. Secara umum, kebijakan pembangunan berkelanjutan di universitas di Indonesia, fokus mengenai masalah perbaikan lingkungan, karena Indonesia masih menghadapi masalah lingkungan sebagai isu utama, sedangkan untuk kebijakan di universitas di Perancis sebagian besar mengadopsi dari rumusan perencanaan Agenda 21.

Universitas Nantes terlihat lebih sustain daripada UNDIP dikarenakan universitas tersebut terletak di Kota Nantes yang sudah mengedepankan pembangunan berkelanjutan. Berdasarkan analisis yang telah dilakukan, penulis menyimpulkan bahwa kebijakan pembangunan berkelanjutan di universitas yang paling ideal adalah yang mampu merespon kebutuhan pengguna dan menjadi solusi bagi permasalahan yang dihadapi oleh universitas dan masyarakat. Kebijakan harus menempatkan tiga pilar pembangunan berkelanjutan dalam program aksi tersebut. Singkatnya, kebijakan terbaik untuk pembangunan berkelanjutan di kampus harus diintegrasikan ke dalam pengelolaan lingkungan hidup, meningkatkan kualitas hidup masyarakat universitas dan penguatan ekonomi dan terlibat dengan semua stakeholder.

\section{DAFTAR PUSTAKA}

Alshuwaikhat, Habib M dan Ismaila Abubakar. 2008. "An Integrated Approach To Achieving Campus Sustainability: Assessment Of The Current Campus Environmental Management Practices," dalam Journal of Cleaner Production 16. 1777e1785. www.elsevier.com/locate/jclepro 
Bovar, Odile et al, 2008. Les indicateurs de développement durable. Dossier Insee. www.insee.fr/fr/ffc/docs_ffc/ref/ECOFRAo8c.PDF.

Budihardjo, Eko dan Djoko Sujarto. 2009. Kota Berkelanjuta. Bandung: PT Alumni.

Budihardjo, Eko dan Sudanti Hardjohubojo. 2009. Wawasan Lingkungan dalam Pembangunan Perkotaan. Bandung: PT Alumni.

Budihardjo, Eko. 1997. Tata Ruang Perkotaan. Bandung : Alumni

DPIL, 2015. «Opération campus « Nouveau Tertre » marché de conception - entretien maintenance pour la réhabilitation du bâtiment Tertre », programme général et architectural. 5 février, l'Université de Nantes.

Humblet, E. M., et al. 2010. Roadmap To a Green Campus. Washington, D.C.: US Green Building Council.

Meng, et al. 2007. Kampus Sejahtera Kampus Lestari: The Genesis For a Sustainable Campus. Malaysia: Corporate \& Sustainable Development Division Universiti Sains Malaysia

Salatin, Joey. 2011. Eco-Campus: Thinking Beyond Green to Truly Sustainable. Jurnal Agres The Voice of Eco- Agriculture. Volume 41 No.6. Amerika

Soetomo, Soegiono. 2012. Urbanisasi dan Morfologi: Proses Perkembangan Peradaban dan Wadah Ruangnya Menuju Ruang yang Manusiawi. Yogyakarta: Graha Ilmu.

Sugiyono. 2008. Metode Penelitian Kuantitatif, Kualitatif, dan R\&D (Qualitative and Quantitative Research Methods). Bandung: Alfabeta.

Yulistiani. 2013. «Pengaruh perubahan guna lahan terhadap pelayanan drainase di kawasan sekitar kampus UNDIP Tembalang ». Tugas Akhir. Universitas Diponegoro. 